\title{
3 Research Suare \\ Sero-Epidemiological Study on Bovine Rota and Coronavirus in Neonatal Calves in Dairy Farms of Addis Ababa, Ethiopia
}

Hayat Abdela Assefa

Jimma University College of Agriculture and Veterinary Medicine

Asaminew Tesfaye

National Animal Health and Diagnostic center, Sebeta,Ethiopia

Motuma Debelo Dibaba ( $\sim$ rabbiinsimage@gmail.com )

Jimma University College of Agriculture and Veterinary Medicine https://orcid.org/0000-0001-64987498

Research article

Keywords: Calf diarrhea, Rotavirus, Coronavirus, Risk factors, Addis Ababa

Posted Date: March 13th, 2020

DOI: https://doi.org/10.21203/rs.3.rs-17360/v1

License: (c) (1) This work is licensed under a Creative Commons Attribution 4.0 International License.

Read Full License 


\section{Abstract}

Background: Bovine rotavirus (BRV) and coronavirus (BCoV) are most commonly associated etiologies from viral causative agents of neonatal calf diarrhea. A cross-sectional study was carried out in randomly selected dairy farms of Addis Ababa from November 2018 to April 2019 with the objectives of estimating the prevalence of bovine rota and coronavirus infection in diarrheic and non-diarrheic calves and determining the associated risk factors. A probability proportional to size sampling technique (PPS) was used and accordingly, the study involved a total of 110 calves under 30 days of age from 57 dairy herds of which $34(59.6 \%), 18(31.6 \%)$ and $5(8.8 \%)$ were small scale, medium scale and large scale farms respectively. As well risk factors associated with herd and calves were obtained from an interview of farm owners.

Results: By using sandwich enzyme-linked immunosorbent assay (ELISA) test, out of these 110 calves, 4 (3.64\%) were found positive for rotavirus while only 1 (0.91\%) was found positive for coronavirus infection. Data generated from both interview and laboratory investigation was analyzed using SPSS version 20. As a result, prevalence of rotavirus infection showed a significant difference $(P<0.05)$ with respect to sex, diarrhea status, colostrum timing and consistency of diarrhea. However, prevalence of coronavirus infection showed significant difference $(P<0.05)$ only with consistency of diarrhea.

Conclusions: In conclusion, rotavirus and coronavirus infection in neonatal calves in this finding showed as there is less prevalence in dairy farms of the study area; therefore, effort should be initiated for further studies on other (infectious and non-infectious) causes of calf diarrhea in this area.

\section{Introduction}

Ethiopia basically constitutes an agrarian society of which a socio-economic activity of about $85 \%$ of the populations is based on farming and animal husbandry. Livestock plays an important role for the majority of the Ethiopian population [41]. Dairy production is one of the critical issues in Ethiopian livestock -based society where livestock and its products are important sources of food and income. Because of better availability of milk market, most of the dairy farms are concentrated in urban and priurban areas of the country. The substantial demand-supply variance in milk and milk products for the major urban centers in Ethiopia is a great opportunity for the development and flourishing of peri-urban dairy farms [1]; [16].

The success of any breeding program as well as the future of dairy farms depends upon the rate of survival of calf produced and accordingly calf morbidity and mortality are of great concern of dairy man because most of the dairy farms are confronted with acute problems of calf morbidity and mortality [39]. Neonatal calf diarrhea is one cause of calf mortality and morbidity. It is a complex of different disease syndromes that causes economic losses directly through mortality and cost of treatment and indirectly from poor growth [29] 
Calf diarrhea is caused as a result of several environmental, management-related, nutritional and physiological factors either alone or in synergy with different infectious agents such as protozoans, bacteria, and/or viruses [4]. Among these infectious agents that have been implicated in calf diarrhea, viruses like bovine coronavirus (BCoV), bovine rotavirus (BRV), and bovine viral diarrhea virus (BVDV), bacteria's like Salmonella species, E. coli ${\mathrm{K} 99^{+}}^{+}$and Clostridium species and protozoa like Cryptosporidium species are some examples [7]; [8]; [33]. Among the viral agents, bovine rotavirus (BRV) and bovine coronavirus (BCoV) are the most commonly associated causes of neonatal diarrhea [27].

According to [19] calf morbidity and mortality was ranked next to mastitis as the second biggest problem for dairy production in Ethiopia. A study done on agents associated with neonatal diarrhea in Ethiopia dairy farms revealed a detection of $\mathrm{BCoV}, \mathrm{BRV}$ and $E$. coli $\mathrm{K}^{\circ} 9^{+}, 38.9 \%, 16.7 \%$ and $11.1 \%$ respectively with no evidence of cryptosporidial infection [2]. Another study on enteropathogens associated with calf diarrhea in dairy farms of Muke-turi, Debre -tsigie and Fitche towns of North Shewa Zone reported prevalence of $E$. coli, salmonella and cryptosporidium as $69.5 \%, 25.7 \%$ and $27.6 \%$ respectively [40].

Though, some studies like the above reports done on general causative agents of calf diarrhea in Ethiopia and in some parts of it, there is still a research gap on major viral causative agents of neonatal calf diarrhea in the urban parts of Ethiopia especially in Addis Ababa. Therefore, the objectives of this study were:

- To estimate the prevalence of bovine rota and coronavirus infection in diarrheic and non-diarrheic calves

- To determine the associated risk factors for BRV and BCoV in dairy farms of Addis Ababa

\section{Material And Methods}

\section{Study Area}

The study was conducted in Addis Ababa which has 117 woredas, 10 sub-cites in which eight of them (Bole, Kolfe Keranio, Yeka, Gullele, Nifas silk-Lafto, Arada, Addis Ketema and Akaky Kality) were visited during the study period. The city is located at a latitude and longitude of $9^{\circ} 1^{\prime} 48^{\prime \prime} \mathrm{N}$ and $38^{\circ} 44^{\prime} 24^{\prime \prime} \mathrm{E}$ respectively [24] and at an altitude of $2500 \mathrm{~m}$ above sea level. It receives an average annual rainfall of $1800 \mathrm{ml}$ and temperature of $21^{\circ} \mathrm{C}$. The relative humidity varies from 70 to $80 \%$ during the rainy season and from 40 to $50 \%$ during the dry season [9]. The economic activities in Addis Ababa are diverse; according to official statistics from the federal government 16,602 peoples are engaged in agriculture. In addition to the residents of rural parts of Addis Ababa, the city dwellers also participate in animal husbandry and cultivation of gardens [24]. Addis Ababa and its peri-urban areas have 62,166 bovine, 22,647 ovine, 7,531 equine, 5,597 caprine and 330,000 avian species [9].

\section{Study animals}


The study animals were neonatal calves in dairy farms up to 4 weeks of age that have or haven't experienced diarrhea which were pure Holstein Frisian or cross breed kept under semi-intensive or intensive management system. All calves with and without history of diarrhea which was born before the study and during the study period less or equal to 30 days old were sampled.

\section{Study design, Sample collection and examination}

The study design was cross-sectional type. One hundred ten (110) fecal samples of approximately 32 grams were collected in sterile tube after cleaning of the anal area with a paper towel from both diarrheic and non-diarrheic calves using disposable latex glove. Samples were placed into sterile universal bottle and labeled; transported to a laboratory by ice box containing ice packs for laboratory analysis. The collected samples were stored at $+4^{\circ} \mathrm{C}$ until time of processing. At the time of sampling the name of the farm, animal ID, sex, age, breed, presence of diarrhea, mortality, consistency of diarrhea, colostrum feeding and timing including its amount and management types were recorded for each calf on proper recording format. Diarrhea was considered if faeces are semi-liquid to liquid, with or without other abnormal characteristics such as presence of blood. Any calf with faeces without these characteristics was considered non-diarrheic or healthy.

Fecal samples allowed to thaw at room temperature and diluted volume by volume into dilution buffer until it allows the pipetting of fecal suspensions. Any gruds were discarded by natural decantation for about 10 minutes. Multiscreen Ag ELISA Calf digestive (BIO K 314/1, Belgium) was used to detect BCoV and BRV antigens in the fecal suspensions. The sandwich ELISA procedure was performed according to the manufacturer instruction as detailed in the kit (Kit reference BIO K 314/1). Any sample that yields a difference in optical density (OD) that is greater than or equal to $600 \%$ (6) for rota and $700 \%$ (7) for coronavirus was considered positive. The test is validated only if the positive control antigens for corona and rotavirus yield difference in the OD at 10 minutes that was $>1000$.

\section{Data analysis}

Data that was generated from laboratory investigation and interview of farm owners was entered and coded into Microsoft Excel 2007 spread sheet and analyzed using SPSS version 20. $\chi^{2}$ value was calculated using descriptive statistics model. The result was considered to have significant difference if $\mathrm{P}<0.05$.

\section{Results}

\section{Overall Prevalence}

The overall prevalence of bovine rota and coronavirus accounted was 4.5\%. As illustrated in Table 1 below, $3.64 \%$ and $0.91 \%$ prevalence for rota and coronavirus was found respectively.

Table 1: Overall prevalence of rota and corona virus in neonatal calves 


\begin{tabular}{lccc}
\hline Viruses & № sampled & № positive & \%Prevalence [95\%CI] \\
& & & \\
\hline Rota virus & 110 & 4 & $3.64[3.6,3.7]$ \\
Corona virus & 110 & 1 & $0.91[0.90,0.92]$ \\
Total & 110 & 5 & $4.55[4.43,4.56]$ \\
\hline
\end{tabular}

\section{Herd and Individual Level Prevalence for Bovine Rotavirus}

The prevalence of rotavirus was high in male (7.3\%) and in 11-20 days of age (7.9\%) calves. The prevalence was also significantly different $(P<0.05)$ with diarrhea, consistency of the diarrhea, colostrum timing and sex. However, the difference was statistically insignificant $(P>0.05)$ in the remaining individual and herd risk factors (Table 2 and 3 ).

Table 2: Association of herd risk factors with rotavirus prevalence 


\begin{tabular}{|c|c|c|c|c|c|}
\hline Risk Factors & № of herd examined & № of positive herd (\%) & $\%$ Prevalence $[95 \% \mathrm{CI}]$ & $x^{2}$ & P-Value \\
\hline Herd size & & & & 2.14 & 0.343 \\
\hline Small scale & 34 & 3 & $8.8[8.65,8.95]$ & & \\
\hline Medium scale & 18 & 0 & $0.0[0.0,0.0]$ & & \\
\hline Large scale & 5 & 0 & $0.0[0.0,0.0]$ & & \\
\hline Total & 57 & 3 & $5.3[5.21,5.4]$ & & \\
\hline Diarrhea & & & & 6.86 & 0.009 \\
\hline Yes & 18 & 3 & $16.7[16.43,16.96]$ & & \\
\hline No & 39 & 0 & $0.0[0.0,0.0]$ & & \\
\hline Total & 57 & 3 & $5.3[5.21,5.4]$ & & \\
\hline Mortality & & & & 3.28 & 0.07 \\
\hline Yes & 28 & 3 & $10.7[10.52,10.88]$ & & \\
\hline No & 29 & 0 & $0.0[0.0,0.0]$ & & \\
\hline Total & 57 & 3 & $5.3[5.21,5.4]$ & & \\
\hline Colostrum feeding & & & & 0.98 & 0.323 \\
\hline Bucket & 49 & 2 & $4.1[4.01,4.19]$ & & \\
\hline Suckling & 8 & 1 & $12.5[12.14,12.8]$ & & \\
\hline Total & 57 & 3 & $5.3[5.21,5.4]$ & & \\
\hline Colostrum timing & & & & 6.8 & 0.033 \\
\hline$<1 \mathrm{hr}$ & 29 & 0 & $0.0[0.0,0.0]$ & & \\
\hline $1-2 \mathrm{hr}$ & 19 & 1 & $5.3[5.14,5.46]$ & & \\
\hline$>2 \mathrm{hr}$ & 9 & 2 & $22.2[21.8,22.62]$ & & \\
\hline Total & 57 & 3 & $5.3[5.21,5.4]$ & & \\
\hline Bedding & & & & 1.35 & 0.246 \\
\hline Yes & 40 & 3 & $7.5[7.37,7.63]$ & & \\
\hline No & 17 & 0 & $0.0[0.0,0.0]$ & & \\
\hline Total & 57 & 3 & $5.3[5.21,5.4]$ & & \\
\hline Colostrum amount & & & & 0.89 & 0.64 \\
\hline$<1 \mathrm{~L}$ & 24 & 2 & $8.3[8.13,8.47]$ & & \\
\hline $1-2 \mathrm{~L}$ & 28 & 1 & $3.6[3.5,3.7]$ & & \\
\hline$>2 \mathrm{~L}$ & 5 & 0 & $0.0[0.0,0.0]$ & & \\
\hline Total & 57 & 3 & $5.3[5.21,5.4]$ & & \\
\hline Calf pen & & & & 0.14 & 0.71 \\
\hline Individual & 25 & 1 & $4[3.88,4.12]$ & & \\
\hline Group & 32 & 2 & $6.2[6.07,6.32]$ & & \\
\hline Total & 57 & 3 & $5.3[5.21,5.4]$ & & \\
\hline
\end{tabular}

Table 3: Association of individual risk factors with rotavirus prevalence 


\begin{tabular}{|c|c|c|c|c|c|}
\hline Risk Factors & № of calf sampled & № of positive calf & \%Prevalence [95\%CI] & $x^{2}$ & P-Value \\
\hline Sex & & & & 4.15 & 0.04 \\
\hline Male & 55 & 4 & $7.3[7.19,7.41]$ & & \\
\hline Female & 55 & 0 & $0.0[0.0,0.0]$ & & \\
\hline Total & 110 & 4 & $9.5[9.42,9.58]$ & & \\
\hline Diarrhea & & & & 6.72 & 0.01 \\
\hline diarrheic & 42 & 4 & $9.5[9.36,9.63]$ & & \\
\hline non-diarrheic & 68 & 0 & $0.0[0.0,0.0]$ & & \\
\hline Total & 110 & 4 & $9.5[9.42,9.58]$ & & \\
\hline Age & & & & 0.47 & 0.79 \\
\hline $1-10 d$ & 31 & 1 & $3.2[3.1,3.3]$ & & \\
\hline $11-20 d$ & 39 & 3 & $7.9[7.77,7.99]$ & & \\
\hline $21-30 d$ & 40 & 0 & $0.0[0.0,0.0]$ & & \\
\hline Total & 110 & 4 & $9.5[9.42,9.58]$ & & \\
\hline Consistency of diarrhea & & & & 30.97 & 0.00 \\
\hline \multicolumn{6}{|l|}{ Normal } \\
\hline Smooth and mucoid & 87 & 0 & $0.0[0.0,0.0]$ & & \\
\hline Watery & 5 & 0 & $0.0[0.0,0.0]$ & & \\
\hline Bloody & 13 & 4 & $30.8[30.41,31.19]$ & & \\
\hline \multirow[t]{2}{*}{ Total } & 5 & 0 & $0.0[0.0,0.0]$ & & \\
\hline & 110 & 4 & $9.5[9.42,9.58]$ & & \\
\hline
\end{tabular}

\section{Herd and Individual Level Prevalence for Bovine Coronavirus}

Eventhough bovine coronavirus was detected in: Small scale farms, herd with diarrhea, farms with bucket type colostrum feeding, farms that use to feed colostrum 1-2 hrs after birth and farms feeding $<1$ liter per day, the herd prevalence was having insignificant difference among those risk factors (Table 4). Moreover, the individual level prevalence was also not significantly different among all risk factors except for consistency of diarrhea (Table 5).

Table 4: Association of herd risk factors with coronavirus prevalence 


\begin{tabular}{|c|c|c|c|c|c|}
\hline Risk Factors & № examined & № positive & $\%$ Prevalence $[95 \% \mathrm{CI}]$ & $x^{2}$ & P-Value \\
\hline Herd size & & & & 0.69 & 0.59 \\
\hline Small scale & 34 & 1 & $2.9[2.81,2.99]$ & & \\
\hline Medium scale & 18 & 0 & $0[0.00,0.00]$ & & \\
\hline Large scale & 5 & 0 & $0[0.00,0.00]$ & & \\
\hline Total & 57 & 1 & $1.8[1.75,1.85]$ & & \\
\hline Diarrhea & & & & 2.2 & 0.14 \\
\hline Yes & 18 & 1 & $5.6[5.44,5.76]$ & & \\
\hline No & 39 & 0 & $0[0.00,0.00]$ & & \\
\hline Total & 57 & 1 & $1.8[1.75,1.85]$ & & \\
\hline Mortality & & & & 1.05 & 0.31 \\
\hline Yes & 28 & 1 & $3.6[3.49,3.71]$ & & \\
\hline No & 29 & 0 & $0[0.00,0.00]$ & & \\
\hline Total & 57 & 1 & $1.8[1.75,1.85]$ & & \\
\hline Colostrum feeding & & & & 0.17 & 0.68 \\
\hline Bucket & 49 & 1 & $2[1.94,2.06]$ & & \\
\hline Suckling & 8 & 0 & $0[0.00,0.00]$ & & \\
\hline Total & 57 & 1 & $1.8[1.75,1.85]$ & & \\
\hline Colostrum timing & & & & 2.07 & 0.36 \\
\hline$<1 \mathrm{hr}$ & 29 & 0 & $0[0.00,0.00]$ & & \\
\hline $1-2 \mathrm{hr}$ & 19 & 1 & $5.3[5.14,5.46]$ & & \\
\hline$>2 \mathrm{hr}$ & 9 & 0 & $0[0.00,0.00]$ & & \\
\hline Total & 57 & 1 & $1.8[1.75,1.85]$ & & \\
\hline Bedding & & & & 0.43 & 0.51 \\
\hline Yes & 40 & 1 & $2.5[2.42,2.58]$ & & \\
\hline No & 17 & 0 & $0[0.00,0.00]$ & & \\
\hline Total & 57 & 1 & $1.8[1.75,1.85]$ & & \\
\hline Colostrum Amount & & & & 1.4 & 0.5 \\
\hline$<1 \mathrm{~L}$ & 24 & 1 & $4.2(4.08,4.32]$ & & \\
\hline $1-2 \mathrm{~L}$ & 28 & 0 & $0.0[0.00,0.00]$ & & \\
\hline$>2 \mathrm{~L}$ & 5 & 0 & $0.0[0.00,0.00]$ & & \\
\hline Total & 57 & 1 & $1.8[1.75,1.85]$ & & \\
\hline Calf pen & & & & 0.79 & 0.37 \\
\hline Individual & 25 & 0 & $0.0[0.00,0.00]$ & & \\
\hline Group & 32 & 1 & $3.1[3.01,3.19]$ & & \\
\hline Total & 57 & 1 & $1.8[1.75,1.85]$ & & \\
\hline
\end{tabular}

Table 5: Association of individual risk factors with coronavirus prevalence 


\begin{tabular}{|c|c|c|c|c|c|}
\hline Risk Factors & № sampled & № positive & $\%$ Prevalence $[95 \% \mathrm{CI})$ & $x^{2}$ & P-Value \\
\hline Sex & & & & 1.01 & 0.32 \\
\hline Male & 55 & 0 & $0.0[0.00,0.00]$ & & \\
\hline Female & 55 & 1 & $1.8[1.75,1.85]$ & & \\
\hline Total & 110 & 1 & $0.91[0.88,0.94]$ & & \\
\hline Diarrhea & & & & 1.6 & 0.2 \\
\hline diarrheic & 42 & 1 & $2.4[2.39,2.47]$ & & \\
\hline non-diarrheic & 68 & 0 & $0[0.00,0.00]$ & & \\
\hline Total & 110 & 1 & $0.91[0.88,0.94]$ & & \\
\hline Age & & & & 1.9 & 0.38 \\
\hline $1-10 d$ & 31 & 0 & $0.0[0.00,0.00]$ & & \\
\hline $11-20 \mathrm{~d}$ & 39 & 1 & $2.6[2.52,2.68]$ & & \\
\hline $21-30 d$ & 40 & 0 & $0.0[0.00,0.00]$ & & \\
\hline Total & 110 & 1 & $0.91[0.88,0.94]$ & & \\
\hline Consistency of diarrhea & & & & 17.49 & 0.01 \\
\hline \multicolumn{6}{|l|}{ Normal } \\
\hline Smooth and mucoid & 87 & 0 & $0.0[0.00,0.00]$ & & \\
\hline Watery & 5 & 1 & $20[19.5,20.54]$ & & \\
\hline Bloody & 13 & 0 & $0.0[0.00,0.00]$ & & \\
\hline \multirow[t]{2}{*}{ Total } & 5 & 0 & $0.0[0.00,0.00]$ & & \\
\hline & 110 & 1 & $0.91[0.88,0.94]$ & & \\
\hline
\end{tabular}

\section{Discussion}

The result of the present study showed that BRV was highly prevalent, 3.64\% (4/110) than BCoV in the study area. There are different rate of BRV infection report in many parts of the world at different times. Eventhough lesser, this result is nearly in agreement with [28] in Costa who reported a prevalence of $7 \%$. Nevertheless, the rate was inconsistent with $25.1 \%$ by [21] in Brazil, $20.2 \%$ by [4] in Brazil, $22.8 \%$ by [42] in Tunisia, 21.84\% by [3] (Akam et al., 2011) in Algeria, 15.68\% by [30] in India and 15.5\% by [5] (Al-Robaiee and Al-Farwachi, 2013) in Iraq. Also much higher rate of $34 \%, 42 \%, 42.7 \%$ and $50 \%$ was reported by [25]; [31] (Reynolds et al., 1986) in England, [14] in Spain and [34] in Scotland respectively. In Ethiopia one study done by [2] revealed $16.7 \%$ which was higher than the current finding. This variation may be due to the lower sample size of this study and difference in the test techniques employed.

On the other hand, $\mathrm{BCoV}$ was detected at a rate of $0.9 \%$ (in only $1 / 110$ samples). This result is lesser when compared to those reported by [34] [13] in India, [14]; [28]; [30] and [31] that was 4\%, 4.76\%, 7.34\%, $9 \%, 11.76 \%$ and $14 \%$ respectively. Much higher rate $19 \%$ and $21.6 \%$ was also reported by [36] in Brazil and [20] in Australia respectively. But almost in agreement with 1.96\% (1/51) reported by [17] in northern Turkey. The variation in prevalence rate among reports may be due to difference in farm management practice, hygienic condition and diagnostic techniques employed [23]; [26].

The association of BRV and BCoV infection was found different in different herd and individual level risk factors. Regarding sex, equal number of male (55) and females (55) were sampled in the study and the 
occurrence of the infections in male (7.3\%) is higher than that of in female (1.8\%). [11] and [10] also reported that as compared to females, male susceptibility for diarrhea was high. This can be explained as size of male at birth is assumed to induce dystocia and consequently decrease colostrum absorption. Plus more care is given to female calves than males because of their economic importance. In contrast, the result reported by [6] and [18] showed that the percentage of females affected by rotavirus is higher than male calves.

The prevalence of both BRV and BCoV was high in calves at the age of 11-20days, 3 (7.9\%) and 1(2.6\%) respectively. This may be due to lack of natural immunity against the two infections and a decrease in passive immunity [35];[38] and [6]. In calves' 1-10days of age, only infection by rotavirus was detected $1(3.2 \%)$. This may be because there was a good neonatal calf care given at this age range in the study area. None of the pathogens were detected in the third age group, 21-30days. These may be justified as: increased natural immunity against the pathogens as calves reach and become beyond 3 weeks old [17]; [37].

All the positive samples for both pathogens were detected from the diarrheic calves ( $9.5 \%$ for BRV and $2.4 \%$ for $\mathrm{BCoV}$ ). The prevalence was significantly different between diarrheic and non-diarrheic calves and its consistency. None of the non-diarrheic calves showed infection by both pathogens in the present study. A study done elsewhere by [12] and [17] revealed no rota and coronavirus antigen detection in nondiarrheic calves respectively. Moreover, the consistency of diarrhea for the positive samples was watery for all rota positives and smooth for the corona positive which is due to effect of the viruses mainly on the small intestine villi [32];[22].

The time for clostrum feeding, feeding types and its amount were also considered in this study. The prevalence of BCoV (2\%) and BRV (4.1\%) was high in herds that feed colostrum with bucket than suckling. This may be due to contamination of buckets with calf feces that also contaminate colostrum while feeding calves. Calves getting colostrum above $2 \mathrm{hrs}$ had shown a high prevalence rate of $22.2 \%$ for rotavirus while $5.3 \%$ prevalence rate for coronavirus was detected in calf feeding within $1-2 \mathrm{hrs}$ in the herd. This may be due to: decline in immunoglobulin transfer across the gut epithelium as the timing increases as well as less frequent adequate colostrum feeding by the farms within the first 12 hours postpartum (even after the first colostrum feeding). A high infection rate of $8.3 \%$ and $4.2 \%$ for BRV and BCoV was found in farms that give colostrum below 1 litter respectively. This can be justified as low amount of colostrum provision to the calves. Rate of FPT decreases in calves that receive $>100 \mathrm{gram}$ of colostral IgG and therefore adequate amount of this IgG mass (>100gram IgG) can be achieved if the calf received 4 liter of colostrum or minimum of 3liter [15].

In conclusion, data from this study showed that both BRV as well as BCoV infection were involved in neonatal calf diarrhea. Therefore, it is advisable if: awareness would be created to dairy farm owners and attendants on overall farm management specifically on proper cow-calf management practice in dairy farms, further studies on other (infectious and non-infectious) causes of calf diarrhea would be carried out and proper vaccination program could be designed for protection of calf diarrhea. 


\section{Declarations}

Ethics approval and consent to participate; the research was ethically reviewed and the use of animals was approved by the Ethics committee of the Jimma University College of Agriculture and Veterinary Medicine. Consent of the owners was obtained to use their animals.

Consent for publication; Not applicable" in this section.

Competing interests; the authors declare that they have no conflict of interest.

Funding; this study was not financially funded but supported by vehicle for data collection and also supported in case of chemicals and reagents used in laboratory processing of data by National Animal Health and Diagnostic Center and Jimma University, College of Veterinary Medicine and Agriculture.

Availability of data and materials; the datasets used and/or analysed during the current study are available from the corresponding author on reasonable request.

Acknowledgement and Authors' contributions; I want to thanks institute of National Animal Health and Diagnostic Center and Jimma University, College of Veterinary Medicine and Agriculture. Also I Thank my main advisor Dr. Motuma Debelo and co advisor Dr. Asaminew Tesfaye for their continuous support, sincere guidance, idea oriented discussion as well as correcting of this paper.

\section{References}

1. Abebe, R., Wossene, A. and Kumssa, B. (2008) Epidemiology of Eimeria infections in calves in Addis Ababa and Around Addis Ababa Dairy Farms, Ethiopia. Int J App Res Vet Med. 6 (1), 24-30.

2. Abraham, G., Roeder, P. and Zewdu, R. (1992) Agents associated with neonatal diarrhoea in Ethiopian dairy calves. Trop Anim Health Prod. 24, 74-80.

3. Akam, A., Khelef, D., Kaidi, R., Rahal, K., Tali-Maamar, H. and Yabrir, B. (2011) The frequency of the shedding of Cryptosporidium parvum, F5 Escherichia coli, rotavirus, coronavirus and Salmonella spp. in young dairy calves in Mitidja area (Algeria). Bull Univ Agric Sci Vet Med. 68, 16-25.

4. Alfieri, A., Parazzi, M., Takiuchi, E., Medici, K. and Alfieri, F. (2006) Frequency of group A rotavirus in diarrheic calves in Brazilian cattle herds, 1998-2002. Trop Anim Health Prod. 38(7-8), 521-526.

5. Al-Robaiee, I. and Al-Farwachi, M. (2013) Prevalence of rotaviral infection in diarrheic neonatal calves in Mosul city, Iraq. Vet World. 6, 538-540.

6. Ammar, M., Mokhtaria, K., Tahar, B., Amar, A., Redha, A., Yuva, B., Mohamed, H., Abdellatif, N. and Laid, B. (2014) Prevalence of rotavirus (GARV) and coronavirus (BCoV) associated with neonatal diarrhea in calves in western Algeria. Asian Pac J Trop Biomed. 4(1), 318-322.

7. Bhat, S., Juyal, P. and Singla, L. (2012) Prevalence of cryptosporidiosis in neonatal buffalo calves in Ludhiana district of Punjab, India. Asian J Anim Vet Adv. 7, 512-520. 
8. Bhat, S., Juyal, P. and Singla, L. (2013) Bovine cryptosporidiosis: brief review of its distribution in India. Tre Para Res. 2, 5-13.

9. CSA (Central Statistical Authority) (2009) Agricultural Sample Survey 2008/2009 [2001 EC]. Report on Livestock and Livestock Characteristics. Addis Ababa, Pp. 120.

10. Chaudhary, K., Singh, B., Prasad, S. and Verma, R. (2013) Analysis of morbidity and mortality rates in bovine in Himachal Pradesh. Vet World. 6, 614-619

11. Clement, C., King, E., Salman, D., Wittum, E., Casper, H. and Odde, G. (1995) Use of epidemiologic principles to identify risk factors associated with the development of diarrhea in calves in five beef herd. J Am Vet Med Assoc. 207, 1334-1338.

12. Crouch, F. and Acress, D. (1984) Prevalence of rotavirus and coronavirus antigens in faeces of normal cows. Canada J Comp Med. 48, 340-342.

13. Dash, K., Kumar K., Goel, A. and Bhatia, K. (2012) Detection of coronavirus antigen by ELISA from diarrheic cow calves in Mathura, India. Vet World. 5, 166-168.

14. De La Fuente, R., Garcia, A., Ruiz-Santa-Quiteria, A., Luzon, M., Cid, D. and Garcia, S. (1998) Proportional morbidity rates of enteropathogens among diarrheic dairy calves in central Spain. Prev Vet Med. 36, 145-152.

15. Dusty, M., Jeff, W., David, C., Douglas, E. and George M. (2000) Passive transfer of colostral immunoglobulins in calves. J Vet Intern Med. 14, 569-577.

16. FAO (2010) Status and Prospects for Smallholder Milk Production. A global prospective. USA.

17. Gumusova, O., Yazici, Z., Albayrak, H. and Meral, Y. (2007). Rotavirus and coronavirus prevalence in healthy calves and calves with diarrhea. Medycnya Weterinaria. 63, 62-64.

18. Hasso, A. and Pandey, R. (1986) Possible sex differences in the susceptibility of calves to rotavirus infection. Canada J Vet Res. 50, 287-288.

19. ILCA (International Livestock Center for Africa) (1994) Annual Program Report 1993/1994. Addis Ababa, Pp. 73-74.

20. Izzo, M., Kirkland, D., Mohler, L., Perkins, R., Gunn, A. and House, K. (2011) Prevalence of major enteric pathogens in Australian dairy calves with diarrhea. Australia Vet J. 89, 167-173.

21. Langoni, H., Linhares, C., De Avila, A., Da Silva, V. and Elias, O. (2004) Contribution to the study of diarrhea etiology in neonate dairy calves in Sâo Paulo state, Brazil. Brazil J Vet Res Anim Sci. 10, 8990.

22. Martella, V., Bányai, K., Matthijnssens, J., Buonavoglia, C. and Ciarlet, M. (2010) Zoonotic aspects of rotaviruses. Vet Microbiol. 140, 246-255.

23. Mayameei, A., Mohammadi, G., Yavari, S., Afshari, E. and Omidi, A. (2010) Evaluation of relationship between Rotavirus and Coronavirus infections with calf diarrhea by capture ELISA. Comp Clin Path. 19, 553-557.

24. NGA: Country Files. Earth-info.nga.mil. Archived from the original on 4 May 2012. 
25. Nourmohammadzadeh, F., Davoudi, Y., Abdollahpour, G. and Nouri, A. (2012) The prevalence of rotavirus in neonatal calf diarrhoea, using electron microscopic examination. Comp Clin Pathol. 21, 1231-1234.

26. Ok, M., Gu, L., Turgut, K., Ok, U., Sen, I. and Gündüz, K. (2009) The studies on the aetiology of diarrhoea in neonatal calves and determination of virulence gene markers of Escherichia coli strains by multiplex PCR. Zoo Pub Health. 56, 94- 101.

27. Oliveira, J., Silva, P., Pacheco, D., Mascarini, M., Ribeiro, G., Alfieri, A., Alfieri, F., Stipp, T., Barros, J. and Borges, S. (2007) Diarrhea in Nellore calves: Clinical and etiologic study. Brazil J Vet Res. 27, 419424.

28. Perez, E., Kummeling, A., Janssen, M., Jimenez, C., Alvarado, R. and Caballero, M. (1998) Infectious agents associated with diarrhoea of calves in the canton of Tilaran, Costa Rica. Prev Vet Med. 33, 195-205.

29. Radostitis, M., Gay, C. and Hinchcliff, W. (2007) Veterinary Medicine. A Text book of diseases cattle sheep, pigs, goat and horse.8th edn. London: Bailier tyndal. 847-1525 pp.

30. Rai, B., Hansha, A., Rai, S., Singh, B., Kumar, H. and Singh, K. (2011) Prevalence of rota and coronavirus infections in calves of Barabanki and Raebareli districts of Uttar Pradesh. Indian $J$ Vet Pathol. 35, 73-74.

31. Reynolds, J., Morgan, H., Chanter, N., Jones, W., Bridger, C. and Debney, G. (1986) Microbiology of calf diarrhoea in southern Britain. Vet Rec. 119, 34-39.

32. Schultze, B., Gross, J., Brossmer, R. and Herrler, G. (1991) The S protein of bovine coronavirus is a hemagglutinin recognizing 9-0-acetylated sialic acid as a receptor determinant. $J$ Virol. 65, 62326237.

33. Singla, D., Gupta, P., Singh, H., Singh, T., Kaur, P. and Juyal, D. (2013) Antigen based diagnosis of Cryptosporidium parvum infection in cattle and buffalo faeces. Indian J Anim Sci. 83, 37-39.

34. Snodgrass, R., Terzolo, R., Sherwood, D., Campbell, I., Menzies, D., Synge, A. (1986) Aetiology of diarrhea in young calves. Vet Rec. 119, 31-34.

35. Steele, D., Geyer, A. and Gerdes, H. (2004) Rotavirus infections. In: Coetzer A., and Tustin, C. (eds). Infectious Diseases of Livestock. 2nd edn. Cape Town, Southern Africa: Oxford University Press. 1256-1264 pp.

36. Stipp, T., Barry, F., Alfieri, F., Takiuchi, E., Amude, M. and Alfieri, A. (2009) Frequency of BCoV detection by a semi-nested PCR assays in faeces of calves from Brazilian cattle herds. Trop Anim Health Prod. 41, 1563-1567.

37. Suresh, T., Rai, B., Wani, Y., Damodaran, T. and Dhama, K. (2013) detection of bovine rotavirus in neonatal calf diarrhoea by ELISA, FAT and transmission electron microscopy. Inter J Curr Res. 5(7), 1935-1939.

38. Uhde, F., Kaufmann, T., Sager, H., Albini, S., Zanoni, R., Schelling, E., Meylan, M., (2008) Prevalence of four enteropathogens in the faeces of young diarrhoeic dairy calves in Switzerland. Vet. Rec. 163, 362. 
39. Wudu, T., Kelay, B., Mekonnen, H., Tesfu, K., (2008) Calf morbidity and mortality in smallholder dairy farms in Ada'a Liben district of Oromia, Ethiopia. Trop. Anim. Health Prod. 40, 369-376.

40. Yenehiwot, B. (2008) epidemiological and microbiological studies of calf diarrhea and pneumonia. Addis Ababa University.

41. Yohannes, A. (2002) Background information on contagious bovine pleuropneumonia in Ethiopia.

42. Zrelli, M., Messadi, L., Benmiled, L., Jemli, H. and Haddad, N. (1990) Infectious agents associated with neonatal calf diarrhea in Tunisia. Rev Med Vet. 141, 861-872. 